\title{
CLIMATOLOGICAL TABLES FOR THE CITY OF DUBLIN,
}

Latitude $53^{\circ} 20^{\prime} \mathrm{N}$. ; Longitude $6^{\circ} 15^{\prime} \mathrm{W}$.; Altitude, 56 feet.

By John Wrlliani Moore, B.A., M.D., M.Ch., Univ. Dubl.; F.K.Q.C.P.; F. R. Met. Soc.

The materials for these Tables were obtained in the preparation of an Abstract of Observations taken in the City of Dublin during the twentythree years, 1865-1887, inclusive. This abstract was compiled at the request of M. L. Cruls, the Director of the Imperial Observatory at Rio de Janeiro, Brazil, who has undertaken to prepare a "Dictionnaire Climatologique Universel," the publication of which will be under the care and at the expense of the Observatory of Brazil.

Table I.-Atmospherical Pressure.

\begin{tabular}{|c|c|c|c|c|}
\hline Year & $\begin{array}{l}\text { Mean Height } \\
\text { of } \\
\text { Barometer }\end{array}$ & $\begin{array}{c}\text { Max. Height } \\
\text { of } \\
\text { Barometer }\end{array}$ & $\begin{array}{l}\text { Min. Height } \\
\text { of } \\
\text { Barometer }\end{array}$ & $\begin{array}{c}\text { Annual Range } \\
\text { of } \\
\text { Pressure }\end{array}$ \\
\hline & Inches & Inches & Inches & Inches \\
\hline 1865 & $29 \cdot 956$ & $30 \cdot 860$ & 28.310 & $2 \cdot 550$ \\
\hline 1866 & $29 \cdot 869$ & $30 \cdot 700$ & $28 \cdot 570$ & $2 \cdot 130$ \\
\hline 1867 & $29 \cdot 952$ & 30.670 & $28 \cdot 600$ & $2 \cdot 070$ \\
\hline 1868 & 29.949 & 30.670 & $28 \cdot 770$ & $1 \cdot 900$ \\
\hline 1869 & $29 \cdot 950$ & 30.610 & $28 \cdot 660$ & $I \cdot 950$ \\
\hline 1870 & $29 \cdot 940$ & $30 \cdot 615$ & $28 \cdot 587$ & $2 \cdot 028$ \\
\hline 1871 & $29 \cdot 886$ & 30.538 & $28 \cdot 460$ & $2 \cdot 078$ \\
\hline 1872 & $29 \cdot 737$ & $30 \cdot 402$ & $28 \cdot 397$ & 2.005 \\
\hline 1873 & $29 \cdot 930$ & $30 \cdot 728$ & $28 \cdot 345$ & $2 \cdot 333$ \\
\hline 1874 & $29 \cdot 944$ & $30 \cdot 866$ & $28 \cdot 556$ & 2.310 \\
\hline 1875 & $29 \cdot 964$ & 30.673 & $28 \cdot 715$ & 1.958 \\
\hline 1876 & $29 \cdot 863$ & 30.662 & $28 \cdot 448$ & $2 \cdot 214$ \\
\hline 1877 & $29 \cdot 852$ & $30 \cdot 700$ & $28 \cdot 303$ & $2 \cdot 397$ \\
\hline 1878 & $29 \cdot 92 \mathrm{I}$ & 30.712 & $28 \cdot 720$ & 1.992 \\
\hline 1879 & $29 \cdot 923$ & 30.717 & 28.820 & $1 \cdot 897$ \\
\hline 1880 & $29 \cdot 964$ & 30.676 & $28 \cdot 373$ & $2 \cdot 303$ \\
\hline 1881 & 29.910 & 30.737 & $28 \cdot 377$ & $2 \cdot 360$ \\
\hline 1882 & $29 \cdot 881$ & 30.935 & 28.718 & $2 \cdot 217$ \\
\hline 1883 & $29 \cdot 923$ & 30.802 & $28 \cdot 573$ & $2 \cdot 229$ \\
\hline 1884 & 29.942 & $30 \cdot 729$ & $28 \cdot 150$ & $2 \cdot 579$ \\
\hline 1885 & 29.902 & $30 \cdot 657$ & $28 \cdot 413$ & $2 \cdot 244$ \\
\hline 1886 & $29 \cdot 884$ & 30.776 & $27 \cdot 758$ & 3018 \\
\hline 1887 & $30^{\circ} 015$ & $30 \cdot 681$ & 28.538 & $2 \cdot 143$ \\
\hline Means & $29 \cdot 916$ & $30 \cdot 701$ & 28.485 & $2 \cdot 216$ \\
\hline
\end{tabular}

The average annual atmospherical pressure in the 23 years has been 29.916 inches.

The average annual oscillation of atmospherical pressure (barometric range) has been $2 \cdot 216$ inches.

The maximal reading of the barometer in the 23 years was 30.935 inches, on January 18, 1882. 
The minimal reading of the barometer in the 23 years was 27.758 inches, on December 8, 1886.

'The extreme barometrical range has been 3.177 inches.

TABLE II.-Temperature, Humidity, Cloud, Rain, and Wind.

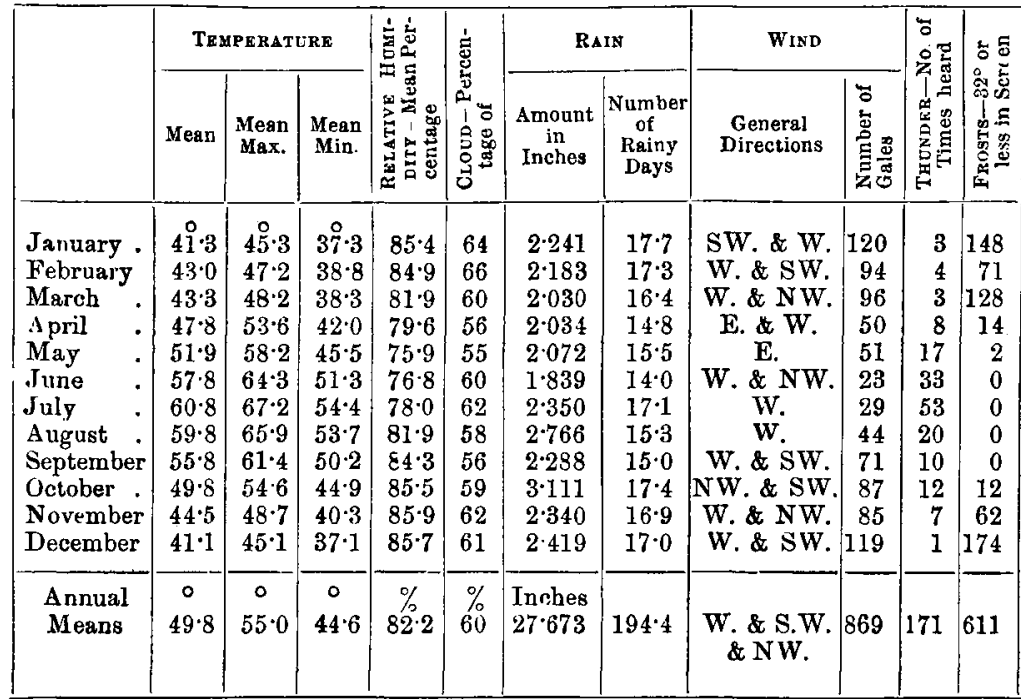

The extreme temperatures recorded in the thermometer screen were:Highest, $87 \cdot 2^{\circ}$, on July 16,1876 .

Lowest, $13 \cdot 3^{\circ}$, on December 14, 1882.

The average relative humidity and the average percentage of cloud are based on 18 years' observations at 9 a.m. and 9 p.m. from 1870 to 1887, both inclusive.

\section{PASGAGE OF A FRACTURED COCCYX PER ANUM.}

Dr. W. J. JoLLY, Waldo, Fla. (Med. Rec.), reports the case of a twentyone year old primipara, who was in labour. Nothing unusual occurred until the head pressed against the coccyx, which did not yield. The forceps were applied and the woman delivered without perinæum laceration. Immediately after delivery she suffered intense pain in the region of the coccyx, for which an opiate was given. On examination some displacement of the coccyx was found. The opiate soon relieved the pain, and the patient did not suffer any more until the ninth day, except that there was some tenderness in this region. She had some slight pain on that day. On the tenth she passed a bone per anum, which proved to be the lower segment of the coccyx. She has had no trouble since. 